folk/ed. Derg, 2021; 27(1):193-210

DOI: $10.22559 /$ folklor.1555

Research Article / Araştırma Makalesi

\title{
Türkiye Üniversitelerinde Alevilikle İlgili Tezler Üzerine Bir İnceleme (1990-2020)
}

\section{A Research of Theses Related to Alevism in Universities of Turkey (1990-2020)}

\section{Aynur Koçak* \\ Almira Koç}

$\ddot{O} z$

Ortaya çıktığı zamanlardan günümüze değin sahip olduğu kültürü, inanışs şeklini ve yaşayış tarzını ağırlıklı olarak sözlü kültür aracılığıyla gelecek kuşaklara aktaran Alevi toplumu, sahip olduğu bu özellikler neticesiyle yıllar boyunca çeşitli araştırmacıların ilgisini çekmiştir. Bugün Anadolu'dan, Ortadoğu'ya, Avrupa'dan Amerika'ya dünyanın birçok bölgesine yayılmış olan Alevi kültürünün tarihi incelendiğinde varlıklarını büyük ölçüde Anadolu'da sürdürdükleri görülmektedir. Gerek Türkiye'de gerekse Türkiye dışında birçok araştırmacının ilgisini çeken Alevi kültürü, özellikle sosyal bilimler disiplinleri bağlamında farklı araştırmaların odağında olmuştur. Söz konusu bu çalışmalar başladıkları ilk yıllardan günümüze değin artış göstermiş, disiplinlerarası çalışmalar eşliğinde oldukça çeşitlenmiştir. $\mathrm{Bu}$ çalışmada Türkiye'de bulunan üniversitelerdeki 1990-2020 yılları arasında gerçekleştirilen lisansüstü tez çalışmaları arasından Alevilik ile ilgili yapılan çalışmalar; yıllara, illere, çalışılan disiplin ağırlıklarına, kullanılan yöntemlere ve konularına

Geliş tarihi (Received): 08.11.2020 - Kabul tarihi (Accepted): 25.01.2021

* Prof. Dr., Yıldız Teknik Üniversitesi Fen- Edebiyat Fakültesi Türk Dili ve Edebiyatı Bölümü Öğretim Üyesi. aynurnazkocak@hotmail.com. ORCID 0000-0002-9555-1088

**Yüksek Lisans Öğrencisi Yıldız Teknik Üniversitesi Sosyal Bilimler Enstitüsü. almirakoc36@gmail.com. ORCID 0000-0003-2956-0119 / CC BY 
göre incelenmiştir. Söz konusu bu çalışmada yapılan tezler konularına göre genel başlıklar altında sınıflandırılmıştır. 1990-2020 yıllarında gerçekleştirilen Alevilik ile ilgili çalışmalara ait veriler ise grafikler aracılığıyla görselleştirilmiştir. Ardından bu grafikler literatür taraması ile elde edilen veriler ışığında yorumlanmıştır.

Anahtar sözcükler : Alevilik, Kızllbaş, üniversite, lisansüstü, bilimsel tez

\begin{abstract}
The Alevi society, which has transferred its culture, belief and lifestyle to future generations mainly through oral culture since its emergence, has attracted the attention of various researches over the years. When the history of the Alevi culture, which has spread to many regions of the world from Anatolia, the Middle East, Europe to America, is examined, it is seen that they continue their existence in Anatolia to a great extent. In Turkey and as well as in other countries, Alevi culture attracted the attention of many researches, especially in the context of the social sciences has been the focus of different research disciplines. These studies considerably with interdisciplinary studies. This study examined the studies related to Alevism between postgraduate theses at universities in Turkey between the years 1990-2020; according to years, provinces, discipline weights, methods used and subjects. The theses made in this study are classified under general titles according to their subjects. The data of studies on Alevism between 1990-2020 have ben visualized through graphics. Then, these graphics were interpreted in the light of the data obtained through the literature review.
\end{abstract}

Keywords: Alevism, Qizilbash, university, postgraduate, scientific thesis

\title{
Extended summary
}

This study focuses on theses related to Alevism culture in universities of Turkey between the years 1990-2020. The purpose of the study is to analyze the general situation of theses related to Alevism in universities of Turkey between the years 1990 and 2020. In the analysis, theses are evaluated in which years, in which aspects and with which methods they were prepared. In that regard, starting from the first studies on the subject prepared in Turkey until today has been looked. In order to reach theses in universities of Turkey between 1990 and 2020, CoHE Thesis Center (YÖKTEZ) website connected to CoHE (YÖK) is used. Because theses prepared in universities of Turkey must be registered to this system. Theses with the terms "Alevi" and "Qizilbash" were found in the thesis summary using the detailed search button of the site. More than 800 studies that emerged as a result of these words were examined, and theses that centered on Alevism or presented data on Alevism were listed since 1990. During this listing, attention has been paid to various characteristics such as the year the thesis was published, its author, name, subject, university and institute it is affiliated with. In line with these features, 585 theses that can be evaluated within the scope of the study were found.

First of all, the distribution of 585 theses examined in the study by universities and provinces is shown through graphics. It has been observed that studies have been carried out 
in most of the country; apart from Istanbul and Ankara, it has been observed that most of the prominent provinces are those with a high populated of Alevis. It was stated that the cities of Istanbul and Ankara were the provinces where the studies were prepared the most, and the main reason for this situation was the higher number of universities in these two provinces compared to other provinces. It has been observed that the establishment and expansion process of the universities in the country has also been effective in the spread and increase of the theses about Alevism throughout the country.

Secondly, the distribution of the theses by years was presented with the help of graphics. In this context, it was observed that there was a great increase in the number of theses, especially between 1995-2000 and 2010-2015. While focusing on the reasons for this increase, the data obtained through the literature review were used. In order to talk about the increases in 1990 and after, it is necessary to reveal the effect of the 1980 period. For this reason, the data obtained from the literature review on economic crises, social and political transformations, technological developments in the world and in Turkey in 1980 and after are presented. In the light of these data, the reasons for the increase in the said periods are discussed. It has been observed how the economic crises and the social transformations created by these crises, the political events in Turkey, and the technological developments around the world affect the increase in these theses. It was concluded that the institutionalization processes of the Alevis and the relations between the European Union and Turkey triggered the increase in the theses.

Thirdly, the theses were examined according to the institute where the theses were prepared, the disciplines they were affiliated to, their subjects and the language of the them. Separate graphics have been put forward for each subject. Considering the institutes to which the theses are affiliated, it has been determined that the social sciences institute is predominantly in the foreground. It was observed that theses on this subject were prepared in twelve different institutes together with the institute of social sciences. When it comes to 585 theses examined, it has been observed that the ratio of interdisciplinary studies to general studies is $38 \%$. While preparing the graphics for the disciplines used in theses, each discipline in interdisciplinary studies was evaluated separately.

Considering the graphic that emerged in this context, it is seen that the two disciplines that come to the fore in the studies on Alevism are religion and sociology. The field research methods of the sociology discipline show themselves in most of the theses. It was also determined that thirty-two different disciplines were used in these studies. When the types of theses are examined, it is seen that most of them consist of master theses. Considering the distribution by languages, it was observed that the theses were written in four different languages, and approximately $89 \%$ of them were written in Turkish.

In the fourth step of the study, 585 theses discussed were classified according to their topics. It has been observed that it is possible to classify the theses into eight separate subheadings when it comes to their subjects. The theses prepared were handled under sub-headings from general to specific, and thesis examples suitable for these topics were also given. These eight subtitles can be listed as follows; "Theses Created Within the Framework of Alevism History", "Theses Created Within the Framework of Religious Aspects of Alevism”, "Theses 
Created Within the Framework of the Political, Social and International Identities of Alevis", "Theses Created Within the Framework of Various Alevi Communities", "Theses Created within the Framework of Alevism and Women", "Theses Created Within the Framework of Concepts Contained in the Alevi Tradition", "Theses Created within the Framework of Alevi Bektashi Literature", "Other Theses Presenting Data on Alevism". Under these headings, which studies can be addressed and what kind of studies can be evaluated under this heading in general are explained in the relevant sections. Afterwards, the tag of thesis studies that can be evaluated under these titles is given as an example.

Considering the theses about Alevism between the years 1990-2020 in the light of all data; there is a serious increase in the number of studies. It was seen that political, social, economic and technological developments in the world and the country played an important role in the increase of scientific studies, and in this direction, it was revealed that the context of that period should not be ignored when examining the scientific studies of any period. It is also noteworthy that studies on Alevism are carried out especially through interdisciplinary studies. At the same time, it was determined that the term Alevi-Bektashi used in the studies changed as the study areas changed. For example, while the term Alevi is generally used when it comes to sociological and anthropological studies, the term Kızılbaş comes to the fore in studies describing the situation of Alevis in the Ottoman period. The term AleviBektashi is generally used when it comes to a common symbol or cultural element (Sufistic symbols, poems, etc.). It was emphasized that interdisciplinary studies should become more widespread in order not to repeat the studies and to reveal more in-depth studies. It was seen that general subjects were predominant in the studies examined, and it was concluded that a process towards more detailed and specific subjects of the theses to be prepared in the future should be started in order for the studies to deepen.

\section{Giriş}

Alevi toplumu inanışlarının temeline oturttukları Hak-Muhammed-Ali ve ehlibeyt sevgisiyle İslam'ın diğer mezheplerinden farklı bir yol izlemektedir. Yaşadıkları coğrafyaların, yaşam koşullarının farklılıkları göz önüne alındığında kültür içerisinde de anlatılan menkıbeler ve ritüellerin uygulanışı açısından farklılıklar görülmektedir. Örnek vermek gerekirse Tokat yöresinde yaşayan Alevilerin semahı, cem töreni ve anlatılarıyla Antalya yöresinde yaşayan Alevilerin semahı, cem töreni ve anlatıları arasında farklılıklar görülebilir. Hatta daha da ilginç bir nokta olarak toplulukların bu kadar uzak olmasına gerek yoktur, aynı şehrin iki farklı köyü arasındaki Alevi toplulukları arasında da farklılıklar görülebilir. Alevilik içerisinde söz konusu bu durum; “yol bir sürek bin bir” sözü etrafında farklılıklara rağmen birleştirici bir unsur olarak ortaya konulur. Alevi kültürünün içerisinde yer alan bu çeşitlilik, genel İslam algısının dışarısında kalan çizgisi, Alevi toplumunun uzun yıllar kendi içerisine kapanık olması gibi unsurlar düşünüldüğünde Alevilik konusunun araştırmacılar için neden çekici bir hale geldiği anlaşılabilir.

Çalışmada 1990-2020 yılları arasında yapılan lisansüstü tez çalışmaları arasından AleviKızılbaş kültürü ile ilgili veri sunanlar seçilerek, son otuz yıl içerisinde yapılan çalışmalarda 
nasıl bir yol kat edildiği ortaya konulacaktır. Bu incelemeyle, yapılan çalışmalardan yola çıkılarak gelecekte yapılacak çalışmalara bir yol haritası sunulması hedeflenmektedir.

Ele alınan lisansüstü tez çalışmaları YÖK'e bağlı bulunan YÖKTEZ sitesi üzerinden detaylı tarama kısmında özet yerine "Alevi”, "Kızılbaş" terimlerinin aratılmasıyla elde edilmiştir. Söz konusu anahtar kelimelerle listelenen 800'den fazla çalışma taranmış, konusu Aleviliği barındıran ya da Alevi toplumuna ait veri sunan çalışmalar ayrıca listelenmiştir. Bu listeleme sonucunda konuyla ilişkili olarak 585 adet teze rastlanmıştır. Söz konusu tezler; yılına, yazarına, konusuna, disiplin(ler)ine, bağlı bulunduğu kurum ve enstitü, danışman hocalarına göre sıralanmıştır. Söz konusu liste son olarak 29 Kasım 2020 tarihinde güncellenmiştir, dolayısıyla 2020 yılı içerisinde yer alan çalışmaların büyük bir kısmını da kapsamaktadır. Bu bağlamda elde edilen veriler grafikler aracılığıyla görselleştirilmiştir. Makalenin 1990-2020 yıllarını kapsamasındaki temel neden, yayımlanan tezlerin özetinde Alevi kavramının geçtiği, YÖKTEZ üzerinden gözlemlenen en eski tezin 1990 yılına ait olmasıdır.

Öncelikle Türkiye üniversitelerinde yapılan tez çalışmalarının üniversitelere ve illere göre dağılımı üzerinde durulacaktır. Ardından çalışmaların yıllara göre dağılımı üzerinde durulacak, bu dağılımın dikkat çeken özellikleri ve bunların sebepleri değerlendirilecektir. Hazırlanan tezlerin, bağlı bulundukları enstitüler, kullanılan disiplinler, tezlerin türleri ve dilleri sunulacak veriler arasındadır. 1990 yılından itibaren tezlerde görülen disiplinlerarası çalışmalar ve kullanılan yöntemler hakkında da değerlendirme yapılacaktır. Ardından söz konusu tezlerin konu çeşitliliği üzerinde durulacaktır.

\section{Tezlerin üniversitelere ve illere göre dağılımı}

Araştırma, eğitim ve öğretim işlevleriyle günümüzün modern üniversite anlayışına sahip eğitim kurumlarının ilk kez Avrupa'da kurulduğu bilinmektedir. 1088 yılında kurulduğu kabul edilen Bologna Üniversitesi, Avrupa'da modern anlamda kurulan ilk üniversite olarak bilinmekte ve bu üniversiteyi Paris, Oxford gibi köklü üniversiteler takip etmektedir (Sargın, 2007: 134-135). Türkiye'de ilk üniversitelerin kuruluşu hakkında birtakım tartışmalar olduğu görülmektedir. Bu tartışmalar Osmanlı İmparatorluğu döneminde kurulan Darülfünun gibi kuruluşların ilk üniversiteler yerine geçebileceği savından hareket etmektedir. Bununla birlikte bugünün modern üniversitesi olarak tanımlayabileceğimiz ilk üniversite olarak; Cumhuriyet'in ilanından sonra 1933 yılında Darülfünun'un yerine kurulan İstanbul Üniversitesi kabul edilmektedir. Osmanlı döneminde kurulan, üniversitelere benzer bir işlev üstlenen Darülfünun'un Cumhuriyet sonrası dönemde beklenen gelişmeyi gösterememesi, modern ihtiyaçlara cevap verememesi nedeniyle kapatılması; sahip olduğu altyapı ile İstanbul Üniversitesi'nin kurulmasına ortam hazırlamıştır. Üniversite olarak kurulmasalar da 1925 yılında Ankara'da bir Hukuk Mektebinin, 1926 yılında Gazi Eğitim Enstitüsü’nün ve 1930 yılında Ziraat Enstitüsü'nün kurulduğu bilinmektedir (Sargın, 136).

Türkiye'de üniversitelerin tarihsel gelişimine bakıldığg zaman Fransa, Almanya, Avusturya ve ABD gibi ülkelerin üniversitelerin kuruluşunda, misyonlarının oluşmasında önemli rol aldıkları görülmektedir (Arap, 2010: 7). Örneğin; Nazi yönetiminden kaçan Yahudi bilim adamlarının Türkiye'ye geldikleri zaman İstanbul Üniversitesi’nde ders vermeleri bura- 
da ayrı bir ekolün oluşmasında etkili olmuştur. Cumhuriyet'in kuruluşundan 1950'li yıllara kadar gelindiğinde Türkiye'de sadece İstanbul Üniversitesi ve Ankara'da kurulan Ankara Üniversitesi'nin varlığından söz etmek mümkündür. Bu tarihten sonra artış gösteren nüfus, gelişen sanayi sektörü, bölgeler arası gelişmişlik farkının artış göstermesi gibi sebepler neticesinde Türkiye'de yeni üniversiteler kurulmaya başlanmıştır (Sargın, 2007; Arap, 2010). İstanbul ve Ankara şehirleri Cumhuriyet'in kurulmasının ardından gerekli altyapıya sahip olmaları nedeniyle üniversiteler için tercih edilen şehirler olmuşlardır. Bu iki şehrin altyapısının uygunluğu, sahip oldukları nüfus ve eğitim oranı, barındırdığı istihdam potansiyeli kurulacak yeni üniversiteler için de bir cazibe merkezi olmasını sağlamıştır. Nitekim günümüzde devlet ve vakıf üniversitelerinin bu iki şehirde yoğunlaşması, bu durumu kanıtlar niteliktedir.

1957 tarihinde kurulan Erzurum Atatürk Üniversitesi’nden sonra 1970’li yıllarda kurulan Boğaziçi Üniversitesi, Dicle Üniversitesi, Çukurova Üniversitesi, Anadolu Üniversitesi, Cumhuriyet Üniversitesi, İnönü Üniversitesi, Furat Üniversitesi gibi üniversiteler göz önüne alındığında Türkiye'de üniversitelerin kurulmasında 1970'li yıllardan itibaren bir artış görüldüğ̈ söylenebilir (Sargın, 2007: 138-139). Özellikle 1980'li y1llar gerek dünyada gerek Türkiye'de küreselleşmenin, ekonomide ve siyasette liberalleşmenin görüldügüü yıllar olması açısından oldukça çalkantılıdır.

Dünya'da ve Türkiye'de yaşanan her ekonomik, sosyal ve siyasal değişim dönemin önemli eğitim kurumları olan üniversitelere de yansımıştır. Söz konusu bu yıllardan itibaren Türkiye'de bir günde açılan toplu üniversiteler görülmeye başlanmıştır. Bu dönemin Türkiye'deki yükseköğretim faaliyetleri açısından bir başka önemi ise vakıf üniversitelerinin de bu dönemde kurulmaya başlanmış olmasıdır (Sargın, 2007: 141). Yaşanan olayların etkileri 1990’lı yıllar ve 2000'li yılların başlarında net bir şekilde görülmektedir. Dönemin koşulları çalışmanın ilerleyen satırlarında daha ayrıntılı bir şekilde ele alınacaktır. 1990-2020 yıllarında Alevilik ile ilgili yapılan lisansüstü tez çalışmalarının üniversiteler bazında illere göre dağılımı incelendiğinde aşağıdaki gibi bir grafik ortaya çıkmaktadır.

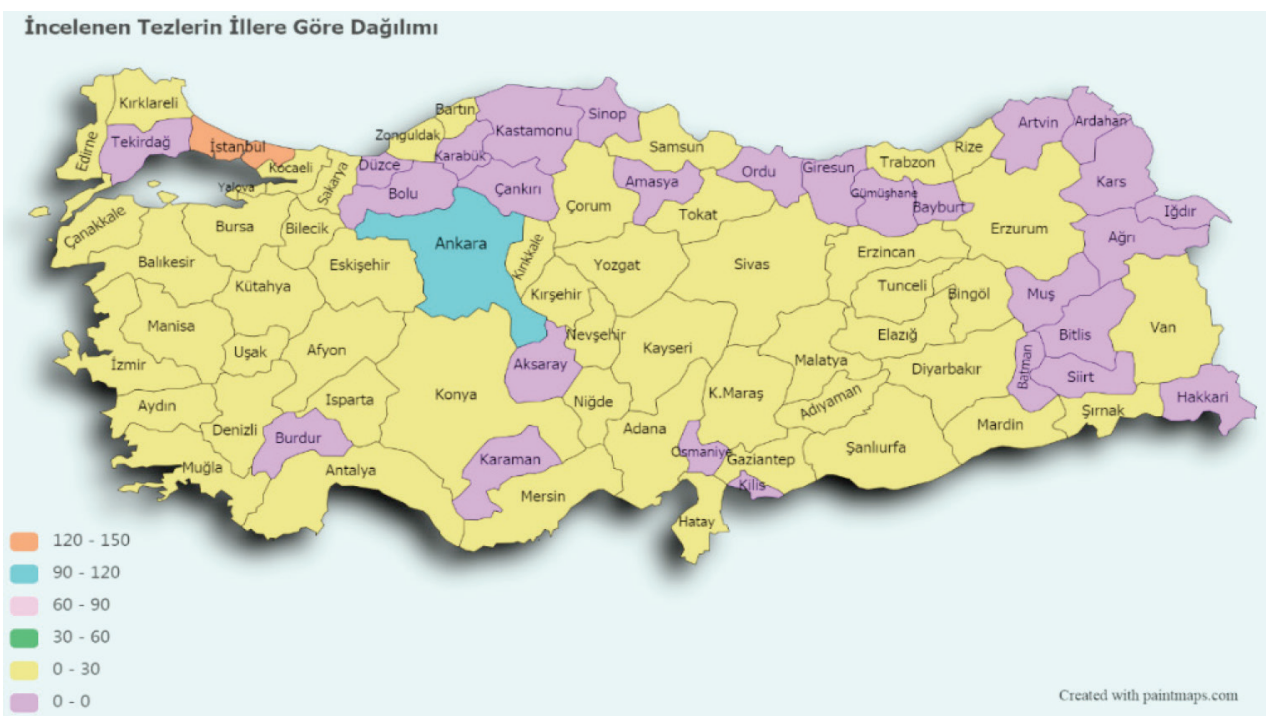


Şekildeki harita grafiğinde de görüldüğü üzere incelenen 585 tezin bağlı bulunduğu üniversiteler ülkenin büyük bir çoğunluğuna yayılmakla birlikte İstanbul ve Ankara şehirleri ön plana çıkmaktadır. Sahip oldukları köklü geçmiş ve altyapıları göz önüne alındığında çalışmaların büyük bir kısmının bu şehirlerde yoğunlaşması şaşırtıcı değildir. İstanbul ve Ankara dışında kalan şehirlere baktığımızda Alevilikle ilgili çalışmaların Ege, Marmara ve İç Anadolu bölgelerinde yoğunlaştığ ve kuzey bölgelerine bakıldığında yeterli çalışmanın yapılmadığı da görülmektedir. İncelenen 585 tezin, 84 farklı üniversite aracılığıyla hazırlandığı tespit edilmiştir. Söz konusu olan üniversitelerin 55 farklı şehre yayıldı̆̆ı gözlemlenmektedir. Bu 84 üniversiteden 70 tanesinin devlet üniversitesi, 14 tanesinin vakıf üniversitesi olduğu tespit edilmiştir. Vakıf üniversitelerinden ikisi günümüzde kapatılmış durumdayken, devlet üniversitelerinin bir kısmı 1990'dan günümüze isim değişikliğine uğramıştır. Üniversitelere ve yapılan tez çalışmalarına ilişkin sayısal veriler göz önüne alındığında, Türkiye içerisinde 1990-2020 yılları arasında Alevilik ile ilgili yapılan tez çalışmaları kapsamında ön plana çıkan iller aşağıdaki pasta grafiğinde net bir şekilde görülmektedir.

Yayımlanan Tez Sayısına Göre Ön Plana Çıkan İller

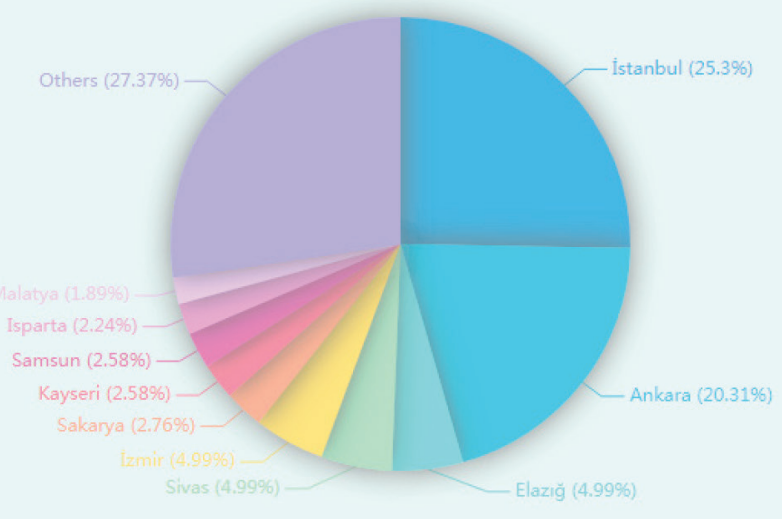

Şekildeki grafikte de görüleceği üzere İstanbul ve Ankara'dan sonra en fazla tez Elazığ ve Sivas illerinde yayımlanmıştır. Sivas’tan sonra İzmir, Sakarya ve Kayseri ön plana çıkmaktadır. İstanbul ve Ankara dışında görülen illerin ortak özelliklerine bakıldığında Alevilerin yoğun bulunduğu iller olmaları ve Anadolu'nun farklı bölgelerinde kurulan ilk üniversitelerin bu şehirlerde yer almaları göze çarpmaktadır.

Yukarıda da bahsedildiği üzere Fırat Üniversitesi, Cumhuriyet Üniversitesi, Dicle Üniversitesi, Erciyes Üniversitesi gibi üniversitelerin Anadolu'da kuruluşu 1970'li yıllara denk gelmektedir. Dolayısıyla 1970'lerde kurulan bu üniversitelerin gerekli altyapıyı sağlamalar1, lisansüstü eğitim için yeterli düzeye ulaşmaları, Anadolu'nun diğer bölgelerinde kalan üniversitelere göre daha erken olmuştur. Bu durum 1990 ve 2000'li yıllardaki çalışmaların İstanbul ve Anlara dışında bu illerde yoğunlaşmasını açıklar niteliktedir.

Haritaya bakıldığında yayımlanan tezler açısından İstanbul ve Ankara'nın bu kadar yoğun olmasının temel sebebi sadece İstanbul'da Alevilikle alakalı tez hazırlayan 8 devlet, 12 
vakıf üniversitesinin olması; Ankara'da ise 8 devlet üniversitesinin yer almasıdır. Oysa ön plana çıkan diğer illere bakıldığında sadece İzmir'de Dokuz Eylül Üniversitesi ve Ege Üniversiteleri nedeniyle iki üniversite bulunmakta diğer şehirlerde birer adet devlet üniversitesi bulunmaktadır. Dolayısıyla yayımlanan tezlerin illere göre yoğunluğu göz önüne alınırken bu durumu akıldan çıkarmamakta yarar vardır.

\section{Tezlerin yıllara göre dağılımı}

YÖKTEZ'den elde edilen veriler 1şığında oluşturulan listeye bakıldığında Alevilik ile ilgili yapılan çalışmaların 1990'dan günümüze ciddi bir artış gösterdiği görülmektedir. Söz konusu bu artışın grafik ile görselleştirilmiş hali aşağıdaki gibidir.

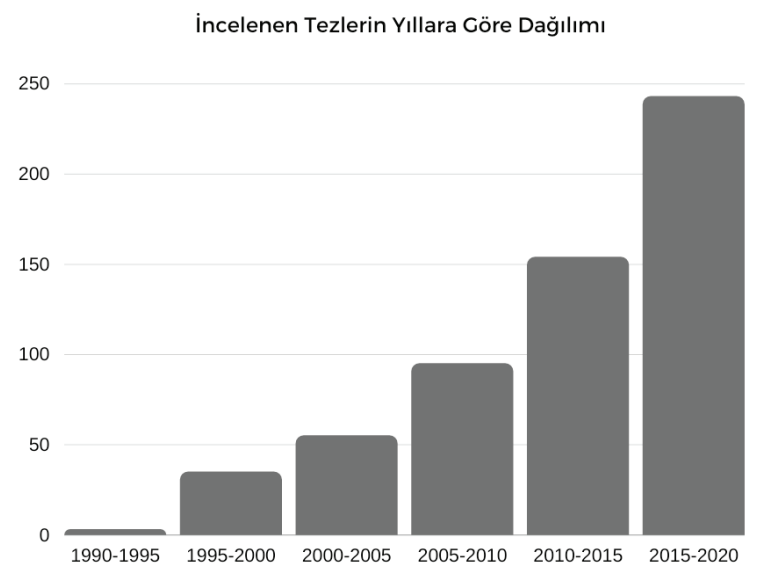

Grafikte de görüldüğü üzere 1995-2000 döneminden itibaren Alevilik ile ilgili yapılan lisansüstü tez çalışmalarında ciddi bir artış görülmektedir. 1990 yılından 2020 yılının Kasım ayına kadar yayımlanan tezler incelendiğinde tez sayılarında görülen bu artışın 1980, 1990 ve 2000-2010 yıllarında yaşanan toplumsal, siyasal ve ekonomik olaylarla, gerçekleşen toplumsal dönüşümle paralel olarak ilerlediği görülebilir. 1990'lı yıllardaki artışın etkisini yakalayabilmek için öncelikle 1980'li yılların siyasal, toplumsal ve ekonomik yönlerini ele almak gerekir. Söz konusu bu yıllar hem ülke içi hem de ülke dışı çalkantılı olayların gerçekleştiği yıllar olarak bilinmektedir. Bu bağlamda öncelikle dünya geneline ardından yaşanan bu gelişmelerin ülke içindeki olayları nasıl etkilediğine bakmakta yarar vardır.

Sanayi devriminden itibaren, teknolojik aletlerin, bilimsel gelişmelerin sosyal, siyasal ve ekonomik yaşamdaki etkileri daha hızlı ve fark edilebilir bir şekilde görülmeye başlanmıştır. 1. ve 2. Dünya savaşlarından sonra toplumun büyük bir bölümünün fabrikalarda çalıştığı, geri kalan kesimlerin tarım ve hizmet sektörleri ile uğraştığı görülmektedir. İşte bu sanayi sektörü ağırlıklı, maddi ürünlerin ön planda olduğu, genel olarak niteliksiz işgüçlerinden oluşan toplum modeli endüstri toplumu kavramıyla ilişkilendirilmektedir (Sapancalı, 1998: 138-140).

Endüstri toplumu, 1970'li yıllarda başlayan dünya çapında ciddi ekonomik, siyasal ve toplumsal dönüşmelere sebep olan ekonomik krizler sebebiyle bir değişim geçirir. 1970’li yıllarda 
başlayan ekonomik krizlerden kurtulmak için 1980’li yıllarda değişiklikler yapılmaya başlanır. Bu dönemde ekonomide serbest piyasa önem kazanmış, özelleştirme uygulamaları artmış ve devletlerin rolleri tartışılmıştır (Sapancalı, 1998: 131). 1980'li yıllarda yapılan bu ekonomik değişimler kamu yönetimi, siyaset gibi alanlarda da kendisini göstermiş, yine aynı dönemde artan teknolojik gelişmeler dünya genelinde çeşitli alanlarda küreselleşmeyi tetiklemiştir.

İletişim ve bilişim teknolojilerindeki gelişmelerle birlikte, endüstri toplumundan bilgi ve hizmet toplumu da denilen post-endüstriyel bir topluma doğru geçiş yaşanmıştır (Sapancalı, 1998: 138-140). Özellikle gelişmiş ve gelişmekte olan ülkelerde görülen bu değişim maddi ürünlerin yerine bilgiyi koyarken, hizmet sektörüne ağırlık vermiş ve dolayısıyla nitelikli eleman ihtiyacında büyük bir artış gözlemlenmiştir. Bu bağlamda dış dünyada yaşanan bu çalkantılı gelişmeler Türkiye'yi de etkilemiştir. 1980'li y1lların Türkiye'sinde görülen siyasi kutuplaşma, artan terör olayları, uzun süren ve bir sonucuna varılamayan seçimler ülkeyi bir kaos ortamına sürüklemekte, ekonomide de ciddi sıkıntılara yol açmaktadır (Küçük, 2019: 21, 26).

Türkiye'de bu ekonomik ve siyasal olayların üzerine bir askeri darbe gerçekleştirilmiştir. Aynı dönemde çıkartılan "1982 Anayasası” ve alınan “24 Ocak Kararları”; Türkiye'de de dünyanın geri kalanı gibi ekonomik, sosyal ve siyasal anlamda bir dönüşüm başlatmıştır. 24 Ocak Kararları’yla birlikte Türkiye ekonomi politikalarında köklü bir değişim yaşanmıştır. Cumhuriyet'in kuruluşundan beri devam eden devletçi ekonomi politikalarının yerine liberal ekonomi politikaları getirilmiştir (Uluç, 2014: 114). Bu politikalar doğrultusunda 1980 Türkiye'sinde serbest piyasaya geçiş başlar ve bu dönemde görülen teknolojik gelişmelerle birlikte, tıpkı gelişmiş ülkelerdeki gibi Türkiye'de de hizmet sektörü çalışanlarında artış görülür (Berber, 2012: 8).

Ekonomi piyasasında görülen bu eğilim, teknolojik gelişmeler ve dünya çapında görülen küreselleşmenin etkisi kendisini kamu yönetiminde de hissettirmiştir. Bu bağlamda 1980'li yıllardan itibaren piyasa temelli bir kamu yönetimi inşa edilmiş, küreselleşme ve çok kültürlü toplulukların ön plana çıkmasıyla siyasi hoşgörü kavramı ortaya atılmış, çatışmaları engelleyecek bir dil seçilmiştir (Kalağan, 2009; Küçük, 2019).

1990’lı yıllara gelindiğinde özgürlük, insan hakları, demokrasi gibi kavramlar ön plana çıkmaya başlamıştır (Kalağan, 2009: 94). Günümüzde olduğu gibi kadın hakları, çevre ve iklim koşulları ile ilgili sorunlar dile getirilmeye başlanmıştır. Kitle iletişim araçlarının gelişimi, Türkiye'de ilk özel televizyonların kurulması, internetin tüm dünya çapında yayılmaya başlaması toplumda farklı algıların, farklı görüşlerin bir arada görünmesine ve değerlendirilmesine zemin hazırlamıştır. Bu siyasal, ekonomik, sosyal ve teknolojik gelişmeler ışığında bir önceki bölümde bahsedilen üniversitelerin kurulma ve yayılma süreçleri bir arada düşünüldüğünde Alevilikle ilgili çalışmaların 1995'li yıllarda ve 2000'li yıllarda gösterdiği artışa dair bazı çıkarımlarda bulunabilir.

Yaşanılan ekonomik, siyasal gelişimlerle birlikte toplum içerisinde de bir dönüşüm başlamıştır. Köyden kente doğru göçlerin artması, şehirlerde hemşeri mahalleleri kurulması, artan nüfus ve nitelikli iş gücüne duyulan ihtiyaç başta büyük şehirler olmak üzere ülkenin birçok farklı şehrinde üniversite kurulma ihtiyacını artırmıştır. Üniversitelerin kurulmasında ihtiyaç duyulan eğitimin yanında politik ve ekonomik sebeplerin ön planda olduğu ileri sürülmektedir. Arap’a göre özellikle 1990'lardan sonraki süreç bir günde çok fazla üniversitenin kurulmasıyla 
“toptan üniversite üretimi” dönemi olarak biçimlenmiştir. Politik iradenin isteği ve ihtiyaçları etrafında şekillenen bu artış, bir günde kurulan toplu üniversiteleri gündeme getirmiştir. (Arap, 2010: 17). Arap, özellikle 1973-1975, 1982, 1992 ve 2006-2008 dönemlerinde altyapısı hazırlanmadan kurulan üniversitelerin kuruldukları illerdeki ticari hayatı canlandırmak ve artan üniversite eğitim talebini azaltma amaciyla kurulduğunu ileri sürerken; Sargın, söz konusu üniversitelerin açılışında ekonomik sebepler ve bölgesel gelişmişlik farkını azaltmak gibi sebeplerin de önemli olduğunu ileri sürmüştür (Arap, 2010; Sargın, 2007). Bu bağlamda bakıldığında 1992-2008 y1lları arasında 62 üniversitenin kurulduğu, bu 62 üniversitenin 42 tanesinin ise sadece 2006-2008 yılları arasında kurulduğu görülmektedir (Arap, 2010: 25). Toptan üniversite açılışların sonucunda Türkiye'de üniversite olmayan bir il kalmamış durumdadır.

Alevilik çalışmalarına bakıldığında 2010-2015 yılları arasından itibaren görülen dikkat çekici artışı 1990'lı yıllardan itibaren kurulan toplu üniversitelerin gerekli altyapıya ulaşarak, lisansüstü eğitimlerinin artması tetiklemiştir denilebilir. Nitekim çalışmanın birinci bölümünde sunulan üniversitelerin dağılımı ve durumları da bu savı destekler niteliktedir.

Sosyal ve siyasal anlamda bakıldığında ise bu çalışmaların artmasını tetikleyen en önemli etkenlerden birinin "1993 Sivas- Madımak Olayları” olduğu söylenebilir. Bu olaylardan sonra Alevilerin toplum içerisindeki görünürlüğü artmaya başlamış, o dönem artmaya başlayan özel televizyon kanalları bu olayları farklı açılardan ele almış, Alevilere yönelik algılar değişmeye başlamıştır. Nitekim Madımak Olayları'nı takip eden süreçte Alevi derneklerinin kuruluşu, kurumsallaşması hız kazanmış, kent içerisinde cemevlerinin kuruluşu ve Alevilerin kimliklerini saklamadan var olma çabaları artış göstermeye başlamıştır. Bu bağlamda merak edilen ve göz önünde olmaya başlayan bir topluluk olarak Aleviler, dikkat çekici bir tez konusu haline gelmiştir denilebilir. Bir diğer önemli etken Türkiye ve "Avrupa Birliği” ilişkilerine dayanmaktadır.

1960’lı yıllarda Ankara Anlaşması ile başlayan ilişkilerin 1980 darbesi sonrasında resmen askıya alındığı görülmektedir. Darbe sonrası dönemde 1987 yılına gelindiğinde Türkiye'nin tam üyelik için başvuru yaptığı ve başvuru sonucunda 1989 yılında kendi iç bütünlügüunü sağlamadan Avrupa Birliği'ne katılamayacağı sonucu çıktığı bilinmektedir (Türkiye-AB İlişkilerinin Tarihçesi, 2020). Bu süreçten sonra 1990’lı yıllarda aday bir ülke konumuna gelen Türkiye, kendi içerisinde sosyal, siyasal ve ekonomik bütünlüğe ulaşmaya çalışmıştır. Avrupa birliğinin Türkiye'deki azınlıklar hakkındaki görüşleri neticesinde, gerekli şartları sağlamak için siyasi iktidarlar tarafından çeşitli açılımlar yapılmıştır ki bunlardan biri de "Alevi Açılımı" olarak bilinmektedir. Dolayısıyla tez sayılarının artmasında Avrupa Birliğine adaylık sürecinin de etkisi bulunmaktadır. Zaten makalenin ilerleyen bölümünde tezlerin içeriğinden bahsedilecektir, Avrupa birliği ve Alevilerle alakalı çalışmaların bulunduğu da görülmektedir.

\section{Tezlerin hazırlandığı enstitü, disiplin, tür, yöntem ve dili}

Çalışmanın daha önceki bölümlerinde incelenen tezler sayısına, bağlantılı oldukları üniversitelere ve illere göre ele alınmıştır. Bu bölümde hazırlandıkları enstitülere, disiplinlere tezlerde uygulanan yöntemlere, kullanılan dillere ait veriler değerlendirilecektir.

Ele alınan 585 tezin bağlı bulundukları enstitülere bakıldığında aşağıdaki gibi bir grafik ortaya çıkmaktadır. 
Tezlerin Bağıı Olduğu Enstitülerin Dağılımı

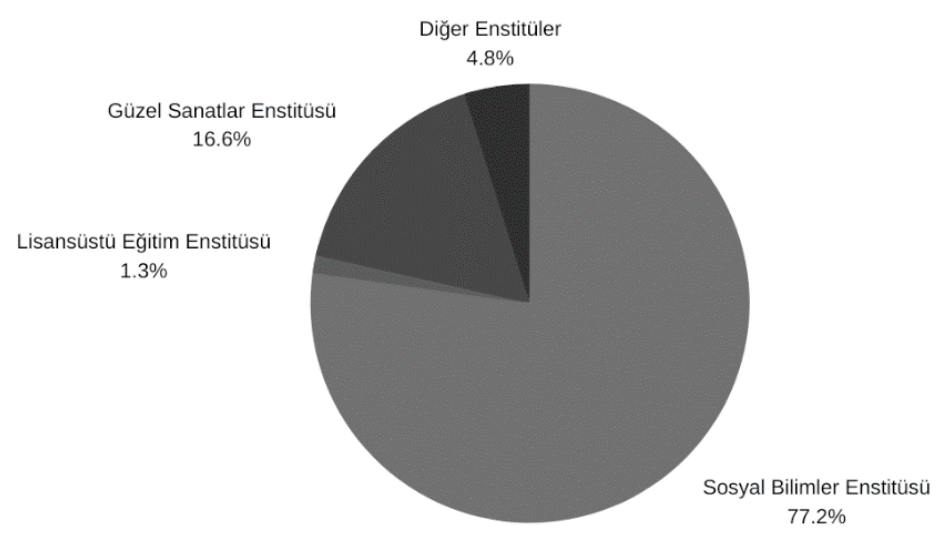

Grafikte görüldüğü üzere incelenen tezlerin çoğunluğunun sosyal bilimler enstitüsüne bağlı olarak hazırlandığı görülmektedir. Genel olarak bakıldığında 13 farklı enstitünün varlığına rastlanılmıştır. Sosyal bilimler enstitüsünden sonra Alevilikte yer alan cem törenleri, semah, zâkirlik, bağlama gibi temel kavram ve ögeleri inceleyen tezlerin yoğunlukta bulunduğu güzel sanatlar enstitüleri karşımıza çıkmaktadır.

Diğer enstitüler kısmında; fen bilimleri enstitüsü, Türkiyat araştırmaları enstitüsü, yaşayan diller enstitüsü, Atatürk ilke ve inkılapları tarihi enstitüsü gibi farklı enstitüler bulunmaktadır. Bu enstitüler aracılığıyla hazırlanan tez sayısının, toplam tez sayısına oranı göz önüne alındığında oldukça düşük bir yüzdeyle karşılaşılmaktadır.

Sosyal bilimler enstitüsü tek başına \%77'lik bir dilimi kapsarken diğer enstitüler kısmında yer alan 10 farklı enstitü ancak \%4,8'lik bir dilimi kapsamaktadır. Sosyal bilimler enstitüsünün bu kadar ağırlıklı olmasının temel sebebi, Alevilikle ilgili hazırlanan tezlerde sosyal bilimlere bağlı disiplinlerin kullanılma sıklığıdır. Bu bağlamda söz konusu tezlerde ön plana çıkan disiplinlere bakıldığında aşağıdaki gibi bir grafik ortaya çıkmaktadır.

İncelenen Tezlerde Ön Plana Çıkan Disiplinler

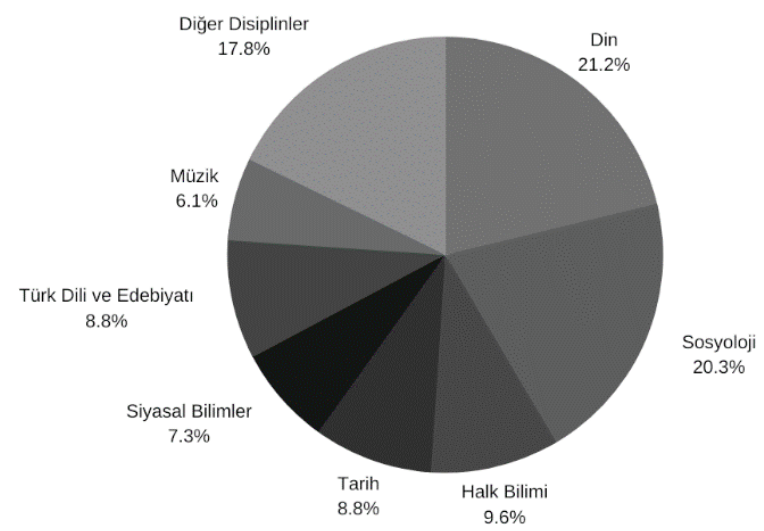


Çalışmalar incelendiğinde; dinden kamu yönetimine, coğrafyadan mimarlığa, dilbilimden ekonomiye, antropolojiden halk bilimine kadar 32 farklı disipline rastlanılmıştır. Ele alınan 585 tezin yaklaşık \%38'ini disiplinlerarası çalışmalar oluşturmaktadır. Disiplinlerarası çalışmalar söz konusu olduğunda en sık kullanılan ikinci disiplinin sosyoloji olduğu görülmektedir. Sosyoloji disiplini; din-sosyoloji, halk bilimi-sosyoloji, siyasal bilimler-sosyoloji, kamu-yönetimi-sosyoloji, tarih-sosyoloji gibi çeşitli disiplinlerle birlikte kullanılmaktadır. Dolayısıyla yukarıdaki grafik hazırlanırken disiplinlerarası çalışmalardaki disiplinlerin her biri ayrı birer disiplin olarak ele alınmıştır.

Alevilik çalışmalarında ön plana çıkan disiplinin din olduğu tespit edilmiştir. Onun ardından da sosyoloji disiplini olduğu görülmektedir. Din çalışmaları genellikle felsefe ve din bilimleri anabilim dalı ve temel İslam bilimleri anabilim dallarının çatısı altında gerçekleştirildiği görülmektedir. Aleviliğin bir mezhep olup olmadığı, cemevlerinin bir ibadethane olup olmadığ1 tartışmaları sürerken en sık din alanında tez çalışmaların yapılmış olması oldukça ilginçtir.

Çalışmada incelenen tezlerin türüne bakıldığında ağırlığın yüksek lisans tezlerinde olduğu görülmüştür. Yüksek lisans tezlerinin doktora tezlerine nazaran daha sık tercih edilmesinde; hazırlanma süresinin dokta tezlerine göre daha kısa olması, konuların doktora tezlerine göre daha genel ve yüzeysel bir şekilde incelenmesinin etkili olduğu söylenebilir. Sanatta yeterlik tezleri ise genele bakıldığında oldukça az bir yer kaplamaktadır. Tezlerin türüne göre dağılımı, aşağıdaki grafikte net bir şekilde görülebilir.

İncelenen Tezlerin Türü

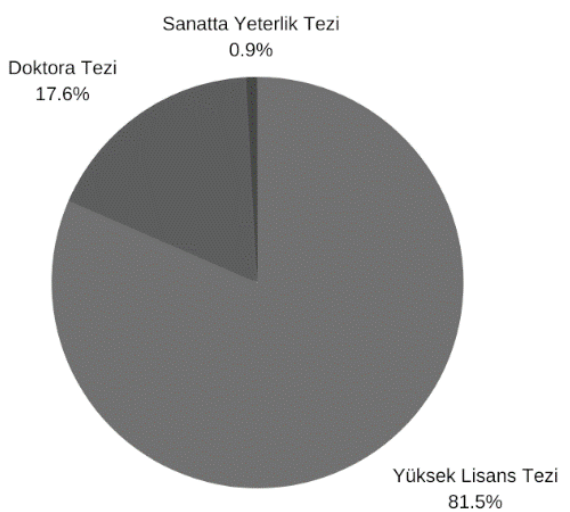

Tezlerde kullanılan yöntemlere bakıldığında ağırlıklı olarak; gözlem, mülakat, anket, literatür taraması gibi yöntemlerle veri toplandığı görülmektedir. Bu durum da verilerin saha araştırması sonucu elde edildiğini ortaya koymaktadır.

Ele alınan 585 tezin diline göre sınıflandırılmasına bakıldığında karşımıza dört farklı dil çıkmaktadır. Tezlerin yaklaşık \%89'unun Türkçe yazıldığı görülürken, Türkçeyi \%10 ile İngilizce takip etmektedir. Tezlerin uluslararası akademik kitlelere hitap etmesi açısından İngilizce yayımlanan çalışmalardaki artış önemlidir. İncelenen çalışmalar içerisinde Türkçe ve İngilizce hariç Fransızca ve Kürtçeye rastlanılmıştır. İngilizce tez çalışmaları söz konusu olduğunda çoğunlukla ODTÜ, Boğaziçi Üniversitesi, Yeditepe Üniversitesi, İhsan Doğrama- 
cı Bilkent Üniversitesi gibi üniversiteler ön plana çıkmaktadır. Fransızca tezler ağırlıklı olarak Galatasaray Üniversitesi ile ilgiliyken, Kürtçe tezler Doğu Dili ve Edebiyatı bölümüyle bağlantılı olarak Mardin Artuklu Üniversitesi ve Bingöl Üniversitesi'nde hazırlanmıştır. Söz konusu tezlerin dillere göre dağılımı aşağıdaki grafikte net bir şekilde ortaya konulmuştur.

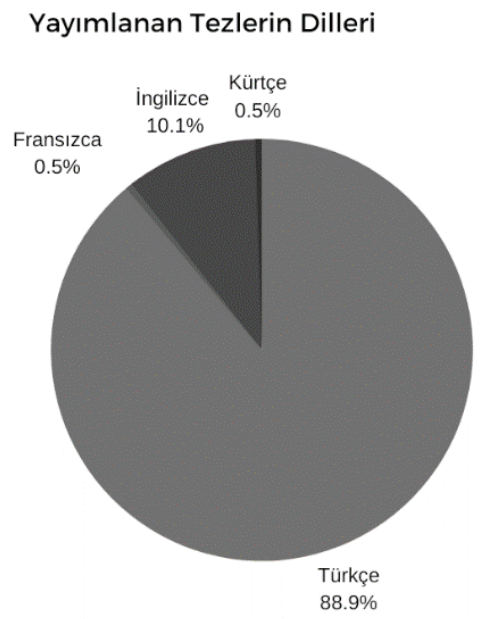

\section{Tezlerin konulara göre sınıflandırılması}

Hazırlanan tezler konularına göre incelendiğinde, tezleri sekiz başlık altında sınıflandırmanın mümkün olduğu görülmüştür. Disiplinlerarası olan çalışmaların bir kısmı sahip oldukları bu özellik neticesinde birden fazla başlık altında incelenebileceğinden bu başlıklar altında sayısal bir veriden söz edilmeyecektir. Çalışmanın bu kısmında bu sekiz başlık ayrıca ele alınacak ve tez örnekleri verilecektir.

\section{Alevilik tarihi çerçevesinde oluşturulan tezler-}

$\mathrm{Bu}$ başlık içerisindeki çalışmalar, Aleviliğin tarihi, Kızılbaşlık, Osmanlı döneminde ve Safevi döneminde Alevilerin durumu, tarihte görülen Kızılbaş isyanları, Kızılbaşlar hakkındaki fetvalar gibi konulardan oluşmaktadır. Bu konularda hazırlanan tezlere şu örnekler verilebilir: "Yıldırım, R. (2008), İki Imparatorluk Arasında Türkmenler: Anadolu'da Kızılbaş Kimliğinin Kökenleri (1447-1514), Doktora Tezi, İhsan Doğramacı Bilkent Üniversitesi, Ankara”; “Aslan, Y. (2012), Yerel ve Sözlü Tarihin Ortaöğretim Öğrencilerindeki Yansımalarl: Tunceli Merkez Örneği, Doktora Tezi, Marmara Üniversitesi, İstanbul”; “Akman, E. G. (2008), On Altıncı Asır Osmanlı Toplumda Belli Başlı Kızılbaş İsyanları, Yüksek Lisans Tezi, Marmara Üniversitesi, İstanbul”; “Arslantaş, Y. (2013), Ötekini Resmetmek: 16. Yüzyıl Osmanlı Tarih Yazımında Kızılbaş Algısı, Yüksek Lisans Tezi, İhsan Doğramacı Bilkent Üniversitesi, Ankara”; “Özkan, M. A. (2018), Fetvalar ve Belgeler Işı̆̆ında Osmanlıda Kızılbaşlık Meselesi (16.-17. yüzyıllar), Yüksek Lisans Tezi, Niğde Üniversitesi, Niğde” 


\section{Aleviliğin dini yönü çerçevesinde oluşturulan tezler}

Bu başlık altında toplanabilecek çalışmalar; Alevilerin dini kimliği, inanış biçimleri, ibadet şekilleri ile ilgilenen çalışmalardır. Aleviliğin İslam dini ve mezhepler tarihindeki yeri de bu çalışmaların ana konularından birisidir. Yapılan inanç coğrafyası çalışmaları, Alevilere dair de veri sunduğundan bu başlık altında ele alınabilir. Yine Sünni-Alevi çatışmaları, Alevilik algısı, Alevilik felsefesi, din eğitimi ve öğretiminde Aleviliğin yeri gibi konular bu başlık altında bir araya getirilebilir. Bu başlık altında olan çalışmalara şu örnekler verilebilir; "Bozkuş, M. (1999), Sivas ve Çevresinde Yaşayan Alevilerin Inançları, Doktora Tezi, Ondokuz Mayıs Üniversitesi, Samsun”; "Kaplan, D. (2008), Buyruklara Göre Kızılbaşlık, Doktora Tezi, Selçuk Üniversitesi, Konya”; “Akçakoca, C. (1997), 20. Yüzyıl Aydın Tarihi ve İnanç Coğrafyası, Yüksek Lisans Tezi, Fırat Üniversitesi, Elazı̆̆"; "Yakar, S. (2011), Alevilikte Hak, Muhammed, Ali İnancl, Yüksek Lisans Tezi, Marmara Üniversitesi, İstanbul”, "Tekelioğlu M. (2013), Alevi-Sünni Evliliklerindeki Çocukların Dini Eğitimi: Malatya Örneği, Yüksek Lisans Tezi, Ondokuz Mayıs Üniversitesi, Samsun”; “Kurt, F. (2016), İlkögretim Din Kültürü ve Ahlâk Bilgisi Öğretim Sürecinde Alevilik Öğretimi, Yüksek Lisans Tezi, Atatürk Üniversitesi, Erzurum"

\section{Alevilerin siyasal, toplumsal ve uluslararası kimlikleri çerçevesinde oluşturulan} tezler

$\mathrm{Bu}$ başlık altında toparlanabilecek çalışmalar Alevilerin kimliklerini ön plana alan çalışmalardan oluşmaktadır. Özellikle Avrupa Birliği-Türkiye ilişkileri bağlamında Alevilerin uluslararası kimliği, siyasal kimliği öne çıkan çalışmalar arasındadır. Yine Alevilerin toplumsal kimlikleri, etnik kimliklerine dair tezler de bu başlık altında yer almaktadır. Alevilerin siyasi kimlikleriyle ilgili olarak; siyasi partilerin Alevilere yönelik söylemleri, açılımları, ya da Alevi partisi olarak bilinen Türkiye Birlik Partisi ile ilgili çalışmalar olduğu görülmektedir.

Siyasal bilimler, kamu yönetimi, uluslararası ilişkiler, hukuk ve sosyoloji alanlarıyla bağlantılı hazırlanan tezler bu başlık altında değerlendirilebilir. Kitle iletişim araçlarında Alevilere yönelik yapılan haberler, yaratılan algıya dair çalışmalar da bu başlık altında değerlendirebilir. Alevilerin siyasal, toplumsal ve uluslararası kimlikleri çerçevesinde hazırlanan tezlerden bazı örnekler verilebilir: "Tombul, I. (2011), Alevi Topluluk Kültürünün Biçimlendirilmesinde Televizyonun Rolü, Doktora Tezi, Ege Üniversitesi, İzmir"; "Pakiş, A. (2005), Kimlik Siyaseti ve Türkiye: Aleviler Üzerine Ampirik Bir Analiz, Yüksek Lisans Tezi, Kocaeli Üniversitesi, Kocaeli”; “Güler, S. (2007), Bir İnanç Sistemi Olarak Aleviliğin Siyasal Örgütlenmesi Türkiye Birlik Partisi Deneyimi (TBP), Yüksek Lisans Tezi, Ankara Üniversitesi, Ankara”; “Tombak, Y. (2012), Avrupa Birliği’ne Üyelik Sürecinde Kolektif Özgürlükler Perspektifinden Türkiye'de Alevilerin Durumu, Yüksek Lisans Tezi, Atılım Üniversitesi, Ankara" ve “Torgut, F. (2019), Etnik Kimlik İş̧asında Mezhep Farklılı̆̆ının Oynadı̆̆ Rol: Zazalar Örneği, Yüksek Lisans Tezi, Yüzüncü Yıl Üniversitesi, Van” 


\section{4. Çeşitli alevi toplulukları çerçevesinde oluşturulan tezler}

Bu başlık altında yer alan tezler, Türkmen, Tahtacı, Nusayri vb. çeşitli Alevi topluluklarına odaklanan tezlerdir. Bu başlık altındaki çalışmalar genellikle sosyolojik, antropolojik çalışmalar olmakla birlikte folklor (halk bilimi) çalışmalarına da rastlanılmaktadır. Söz konusu çalışmalar belli Alevi topluluklarının yaşam tarzı, geçiş törenleri, sahip oldukları anlatılar, sosyal ve ekonomik durumları, yaşadıkları bölgeler gibi konulara dair veriler sunmaktadır. Çeşitli Alevi toplulukları çerçevesinde hazırlanan tezlerden bazıları şunlardır: Çıblak, N. (2001), Iç̧el Tahtacıları-Dini Inanışlar ve Dini Törenler, Halk Kültürü, Anonim Halk Edebiyatı-, Doktora Tezi, Çukurova Üniversitesi, Adana”; "Batuman, S. (2003), Adana Nusayrileri Dini InanışlarTörenler-Halk Kültürü, Yüksek Lisans Tezi, Çukurova Üniversitesi, Adana”; "Büyükokutan, A. (2005), Muğla Yöresi Alevi Türkmenlerinin Halk Edebiyatı ve Folklor Ürünleri Üzerine Bir Araştırma, Yüksek Lisans Tezi, Balıkesir Üniversitesi, Balıkesir”; “İşoğlu, İ. M. (2005), Nusayrilerde İnanç Bağlamında Etnisite ve Toplumsal Cinsiyet İlişkileri, Yüksek Lisans Tezi, Hacettepe Üniversitesi, Ankara”; "Kocadayı, A. (2013), Kaşdişlen Tahtacılarının Dini ve Sosyo-kültürel Yapısı, Yüksek Lisans Tezi, Marmara Üniversitesi, İstanbul”

\section{Alevilik ve kadın çerçevesinde oluşturulan çalışmalar}

$\mathrm{Bu}$ başlık altında yer alan tezler, Alevilikte kadının yeri, Alevi kültüründe analık gibi konularla ilgilidir. Yine bazı toplukları kadın bağlamında (örneğin göç eden ya da bir bölgede yaşayan) inceleyen sosyoloji çalışmalarında karşılaştırmalı olarak Alevi kadınlarına da yer verilmesi, söz konusu tezlerin bu başlık altında değerlendirilmesine olanak sağlar. Bu tezlerden bazıları şunlardır:“Baysu, G. (2002), Yoksul Hanelerdeki Kadınların Yoksulluğuna Bakış, Yüksek Lisans Tezi, İhsan Doğramacı Bilkent Üniversitesi, Ankara”; "Boztepe, M. (2005), İki Göç Arasında Yalnız Anne Olarak Kadın, Yüksek Lisans Tezi, Ege Üniversitesi, İzmir”; "Ekal, B. (2006), Farklılıklar ve Ortaklıklar: Kadınların Alevilik Deneyimleri, Boğaziçi Üniversitesi, İstanbul”; “Gümüş, N. (2011), Alevilikte Kadın: Şahkulu Sultan Dergâhındaki Kadınların Alevi Kadını Algılayışı, Yüksek Lisans Tezi, Dumlupınar Üniversitesi, Kütahya”; "Yetkin, N. (2012), Abdal Alevilerinde Toplumsal Kimlik ve Kadın (Antalya Örneği), Yüksek Lisans Tezi, Süleyman Demirel Üniversitesi, Isparta"; "Koçer, V. (2020), Anadolu Aleviliğinde Kadın Önderler ve Analık, Yüksek Lisans Tezi, Kocaeli Üniversitesi, Kocaeli”

\section{Alevi geleneği içerisinde yer alan kavramlar çerçevesinde oluşturulan tezler}

Alevi kültürü içerisinde önemli bir yer eden belli başlı kavramları içeren tezler bu başlık altında ele alınmıştır. Örneğin cem ritüeli, semah, zâkirlik, dedelik, ocak, Alevi müziği gibi kavramlar etrafında oluşturulan tezler bu başlık altında yer almaktadır. Bu tezlerde antropoloji, sosyoloji, halk bilimi, güzel sanatlar gibi disiplinler ön plana çıkmaktadır. Bu konuları içeren tezlere örnekler şu şekildedir: "Coşkun, S. (1994), Sivas Semah ve Halaylarının Karşılaştırılması, Yüksek Lisans Tezi, İstanbul Teknik Üniversitesi, İstanbul”; "Karaelma, B. (2003), Orta Asya'dan Anadolu'ya Kopuzun (Bağlamanın) Seyri, Yüksek Lisans Tezi, Atatürk Üniversitesi, Erzurum”; "Bakır, A. (2009), Alevilik'te Erkan ve Düşünlük, Yüksek 
Lisans Tezi, Marmara Üniversitesi, İstanbul”; "Çalışkan, S. (2010), Alevilik’te Dört Kapı Kırk Makam, Yüksek Lisans Tezi, Marmara Üniversitesi, İstanbul”; “Özdemir, N. (2012), Çorum Alevileri’nde Kamberlik Geleneği, Yüksek Lisans Tezi, Gazi Üniversitesi, Ankara”; "Küçük, F. (2016), Alevi-Bektaşi Kültüründe Ocak Sistemi: Seyyid Cemal Sultan Ocağı Örneği, Yüksek Lisans Tezi, Nevşehir Hacı Bektaş Veli Üniversitesi, Nevşehir”

\section{Alevi-Bektaşi edebiyatı çerçevesinde oluşturulan çalışmalar}

Alevi-Bektaşi şiir geleneği, sözlü geleneği ile ilgili hazırlanan tezler; divanlar, cönkler ve âşıklarla ilgili yapılan tezler bu başlık altında yer alır. Bu tezlerde Alevi-Bektaşi şiir geleneği içerisindeki âşık ve şairlerin hayatlarının ve eserlerinin incelendiği de görülmektedir. Türk edebiyatında Alevi-Bektaşi kültürü de çalışılan konular arasında yer almaktadır. Bu başlık altında yer alan tezlere şu örnekler verilebilir: "Çongar, E. (1999), Sivas Kaynaklı Cönkler Üzerine, Yüksek Lisans Tezi, Cumhuriyet Üniversitesi, Sivas"; "Demirci, Y. O. (2010), Kadimi Divanı, Yüksek Lisans, Gazi Üniversitesi, Ankara”; “Akın, B. (2009), Asşık Mah Turna 'nın Hayatı, Edebi Kişiliği ve Şiirleri, Yüksek Lisans Tezi, Dicle Üniversitesi, Diyarbakır”; "Yavuz, C. (2013) Alevi-Bektaşi Geleneğindeki Düvazimamlar Üzerine Bir Araştırma, Yüksek Lisans Tezi, Balıkesir Üniversitesi, Balıkesir”; "Sarkın, M. U. (2014), Türk Romanı ve Öyküsünde Alevilik-Bektaşilik, Yüksek Lisans Tezi, Gaziosmanpaşa Üniversitesi, Tokat”

\section{Aleviliğe dair veri sunan diğer çalışmalar}

1990-2020 yılları arasında Aleviliğe dair veri sunan 585 farklı tez incelendiğinde yukarıdaki genel sınıflandırmanın dışında kalan bazı çalışmalara rastlanılımıştır. Bu çalışmalar; ayrı ayrı başlıklar altında toplanacak kadar sayısal bir çoğunluğa sahip olmadıklarından dolayı diğer çalışmalar başlığı altında toplanmıştır. Söz konusu bu çalışmalarda; bilim adamı ya da tarihi kişiliklerin Alevilik hakkındaki düşüncelerine ya da Aleviliğe dair veri sunan bazı çalışmaların değerlendirilmesine, Aleviliği merkeze almasa da Aleviliğe dair veri sunan sosyolojik, antropolojik ağırlıklı çalışmalara, halk oyunları ile ilgili çalışmalara (içerisinde Alevi kültüründe bulunan oyunlar da dahil), monografilere, toplumsal ve siyasal olaylara rastlanılmaktadır. Bu konudaki bazı tezlere; "Bozkurt, S. (1996), Cumhuriyet Tiyatrosunda Oyunlara Yansiyan Törensel Öğeler, Doktora Tezi, Dokuz Eylül Üniversitesi, İzmir”; "Meşe, G. (1999), Sosyal Kimlik ve Yaşam Stilleri, Doktora Tezi, Ege Üniversitesi, İzmir”; "Sumbas, A. (2006), Antakya 'daki Etnik Yapılanmanın Siyasal Hayata Etkileri, Hacettepe Üniversitesi, Ankara”; “Küp, E. (2010), Yusuf Ziya Yörükân'ın Dinler Tarihi Bilimindeki Yeri, Yüksek Lisans Tezi, Erciyes Üniversitesi, Kayseri”; “Ayaz, B. (2013), Balıkesir Yöresinde Kan Bağı ve Evlilik Dışı Akrabalık İlişkileri Üzerine Bir Değerlendirme, Doktora Tezi, Balıkesir Üniversitesi, Balıkesir" örnekleri verilebilir.

Yine fen bilimleri enstitüsü, yaşayan diller enstitüsü, Türkiyat enstitüsü gibi diğer enstitüler kısmında yer alan bazı enstitüler aracılığıyla hazırlanan tezler de bu başlık altında yer almaktadır. Bu tezlere ise; “Turp, D. (2011), Bedâiyü'l Vekâyi (17. yüzyıl) Metin-Dizin-Inceleme, Marmara Üniversitesi, İstanbul”; "Kurtarır, E. (2012), Bir Planlama Sorunsalı Olarak Kültür ve Kent, Doktora Tezi, Y1ldı Teknik Üniversitesi, İstanbul”; "Ülger, G. (2013), Tapınma Ritüeli İle İbadet Mekânı Arasındaki İlişkinin Göstergebilimsel Bă̆lamda 
Okunması: Cemevi Yapıları, Yüksek Lisans Tezi, İstanbul Teknik Üniversitesi, İstanbul"; Atlı, H. (2020), Halk Anlatılarının Etno-dini Topluluklar Arasındaki Değişimi (Alevi ve Ezidi Kürtleri Örneği), Doktora Tezi, Bingöl Üniversitesi, Bingöl” çalışmaları örnek verilebilir.

Görüldüğü üzere 1990-2020 y1lları arasında gerçekleştirilen çalışmalar söz konusu olduğunda çalışmaların büyük bir kısmı belli başlıklar altında toparlanabilmektedir. Bu durum aslında son yirmi yılın Alevilikle ilgili yapılan çalışmalardaki konu çeşitliliğini de ortaya koymaktadır. Alevi kültürü sahip olduğu sözlü kültür ve gelenekler, yaşayış ve inanış biçimi açısından her ne kadar cezbedici bir konu haline gelse de bu konularda yapılan çalışmaların bir kısmının birbirini tekrar eder nitelikte olduğu, çalışmaların çoğunun genel ve yüzeysel olduğu görülmektedir. Burada anlatılmak istenen genel ve yüzeysel olma durumu Alevi toplumunu, Alevi kültürünü ele alış biçimlerinden kaynaklanmaktadır. Alevi kültürüne ait geleneklere, yaşam ve kültür öğelerine, folklor ürünlerine, Alevilik içerisindeki anlatılara, geçiş törenlerine yönelik daha derin, çok katmanlı ve disiplinlerarası çalışmaların yapılması gerekmektedir.

\section{Sonuç}

Bu makalede 1990-2020 yılları arasında Alevi kültürüne ait veriler sunan lisansüstü tez çalışmaları üzerine genel bir değerlendirme yapılmıştır. Yukarıda ortaya konulan veriler ekseninde görülmektedir ki 1990 yılından günümüze değin yapılan lisansüstü tez çalışmalarında Aleviler ile ilgili konular ciddi bir artış göstermiştir. Söz konusu çalışmalara yönelik bu artış, çalışmaların gerçekleştirildiği dönemlerde yaşanan sosyal, siyasal ve ekonomik olaylardan bağımsız düşünülemez.

1980 döneminden itibaren gerek dünya genelinde gerekse Türkiye içerisinde yaşanan siyasal, ekonomik ve sosyal gelişmelerin Alevilikle ilgili çalışmalara etki ettiği görülmektedir. Dünya genelinde yaşanan ekonomik krizlerin dünya ve Türkiye toplumunda yaşattığı siyasal ve toplumsal dönüşmeler, üniversite sayılarındaki artış, Türkiye içerisinde yaşanan sağ-sol çatışmaları, 1980 Darbesi, Alevi-Sünni çatışmaları, darbe sonrası siyasal yaşamın değişmesi gibi etmenler bu çalışmaların artış göstermesini tetiklemiştir. Gittikçe gelişen bilişim ve iletişim teknolojileri, kitle iletişim araçlarındaki yaygınlaşma ve gelişim, internet kullanımının etkisiyle küreselleşen dünya ve bilginin toplum içerisindeki tüketilme hızı, gittikçe artan yabancı bilimsel yayınların çevirileri gibi etmenler de bu çalışmalara etki etmiştir.

1990-2020 yılları arasında gerçekleştirilen çalışmaların büyük bir çoğunluğunun sosyal bilimler enstitüleri içindeki anabilim dallarına bağlı olarak hazırlanmıştır. Sosyal bilimler içerisinde de en üst sırayı din ve sosyoloji disiplinleri almaktadır. Özellikle sosyolojinin veri toplama ve inceleme yöntemleri disiplinlerarası çalışmalara ağırlık vermiştir. 585 tezin yaklaşık \%38'inin disiplinlerarası çalışmalardan oluştuğu, tezlerin \%81'inin ise yüksek lisans tezi olarak hazırlandığg tespit edilen diğer sonuçlar arasındadır.

Çalışmada ele alınan tezlerin genel başlıklar altında sınıflandırılabileceği görülmüştür. Bu sınıflandırma, söz konusu çalışmaların çeşitlilik açısından belli sınırları olduğunun göstergesidir. Alevilik ile ilgili yapılan çalışmaların ağırlıklı olarak Alevileri dini yönden ele alan çalışmalar olduğu görülmüş, bu çalışmaları ise Alevi topluluklarını inceleyen çalışmaların takip ettiği sonucuna varılmıştır. 
Alevilikle ilgili çalışmalarda kadına ayrı bir yer verilmesi, feminist kuramların Alevi çalışmalarında da kullanılması, Alevi kültüründe kadının sahip olduğu konumun genel toplumsal algının dışında olduğunu da göstermektedir.

Söz konusu çalışmalar incelenirken rastlanılan bir başka detay ise inanç, sosyoloji, antropoloji ve siyasal bilimler gibi alanlarda çalışmalar söz konusu olduğu zaman sıklıkla Alevi teriminin, Osmanlı dönemi ve öncesinden bahsedilirken Kızılbaş teriminin, edebiyat ve kültür ögeleri incelenirken (şiirler, nefesler vb.) ise Alevi-Bektaşi terimlerinin kullanılmasıdır. $\mathrm{Bu}$ durum Alevi-Bektaşi teriminin, daha çok ortak terim ve kültürel semboller söz konusu olduğunda kullandığını düşündürmektedir.

Çalışmanın son bölümünde de bahsedildiği üzere Aleviliğe yönelik yapılan çalışmaların genel konular yerine daha spesifik konularla sınırlandırılması, disiplinlerarası yöntemlerden daha fazla faydalanılması bu alandaki çalışmaların çok daha derin ve nitelikli olmasına katk1 sağlayacaktır. Örneğin sözlü kültüre dayalı olan Aleviliğin temel anlayışına hâkim olan, kuşaklarca aktarılan sözlere odaklanılması, giyim kuşam kültürünün ayrıca ele alınması, Alevilerin tarih boyunca yaşadıkları coğrafyaların ayrıca ele alınıp bu coğrafyaların Alevi kültürüne yaptığı katkıların ortaya konulması gibi genel çalışmalara nispeten sınırlandırılmış konular bu alanda daha derin çalışmaların yapılmasını, Aleviliğin çok daha net ve kesin bir şekilde ortaya konulmasını sağlayacaktır.

\section{Kaynaklar}

Arap, K. (2010). Türkiye yeni üniversitelere kavuşurken: Türkiye'de yeni üniversiteler ve kuruluş gerekçeleri. Ankara Üniversitesi SBF Dergisi, 1-29.

Berber, G. (2012). Türkiye'de sosyal tiplerin evrimi ve 1980 sonrasında seçkinlerin kültürel dönüşümü. Karadeniz Teknik Üniversitesi İletişim Araştırmaları Dergisi, 2-12.

Kalağan, G. (2009). 1980 sonrası geleneksel bürokratik yönetim paradigmasında değişim ve yönetsel-siyasal yeniden yapılanma arayışları. Süleyman Demirel Üniversitesi Vizyoner Dergisi, 92-103.

Küçük, A. (2019). Türkiye'de sosyal ve siyasal değişim:1980 ve sonrası. Ecoharran Harran Üniversitesi İIBBF Dergisi, 20-45.

Sapancalı, F. (1998). 1980 sonrası ekonomik gelişmelerin işgücü ve istihdama etkisi. Kamu İş- İş Hukuku ve İktisat Dergisi, 131-159.

Sargın, S. (2007). Türkiye'de üniversitelerin gelişim süreci ve bölgesel dağılımı. Süleyman Demirel Üniversitesi Sosyal Bilimler Enstitüsü Dergisi, 133-150.

Uluç, A. (2014). Liberal muhafazakâr siyaset ve Turgut Özal'ın siyasi düşüncesi. Yönetim Bilimleri Dergisi, 107-140.

\section{Elektronik kaynaklar}

Başkanlığı, T. D. Türkiye-AB ilişkilerinin tarihçesi. T.C Dış Işsleri Bakanlı̆̆ Avrupa Işsleri Başkanlı $\breve{g} l$ : Erişim Tarihi: 10.12.2020 https://www.ab.gov.tr/turkiye-ab-iliskilerinin-tarihcesi_111. $\mathrm{html}$ adresinden alınd. 